\title{
Outsourcing Failure and Reintegration: The Influence of Contractual and External Factors
}

\author{
Sandro Cabral* \\ Federal University of Bahia \\ School of Administration \\ Av. Reitor Miguel Calmon, s/n - Salvador, Bahia, Brazil, 40110-903 \\ E-mail: scabral@ufba.br \\ Bertrand V. Quelin \\ HEC Paris \\ 1, rue de la Libération - 78351 Jouy-en-Josas - France \\ E-mail: quelin@hec.fr \\ Walmir Maia \\ Federal University of Bahia \\ School of Administration \\ Av. Reitor Miguel Calmon, s/n - Salvador, Bahia, Brazil, 40110-903 \\ E-mail: walmir.maia@uol.com.br
}

Paper to be published in the Long Range Planning Journal

2013

\begin{abstract}
This paper discusses the reasons that drive organizations to interrupt outsourcing, reverse their previous decision, and then reintegrate activities formerly delegated to providers. Contractual approaches, mainly derived from Transaction Costs Economics, offer some plausible explanations for reintegration originating from outsourcing failure. These explanations are mainly related to asset specificity, poor contractual design, and deficient monitoring. The study of a real case of outsourcing interruption in industrial maintenance illustrates these different factors. However, some other determinants might complement the contractual and strategic background, namely bandwagon behavior and institutional pressure exerted by external actors. Finally, we propose an integrative framework that combines micro- and macro- levels of organizational analysis. We argue that some existing complementarities between the different theories we use here can shed some light on real organizational problems. Besides the implications for theory, our work can help managers to understand the dynamics of organizational boundaries, thus allowing them to make better choices in both outsourcing and reintegration decisions.
\end{abstract}

Keywords: Reintegration, outsourcing failure, contracting, isomorphism.

* Corresponding author 


\section{Outsourcing Failure and Reintegration: The Influence of Contractual and Environmental Factors}

"Kellwood's multi-million dollar IT outsourcing deal with EDS served it well for many years. But after significant organizational changes and intense investigation of the 13-year deal, it became clear that insourcing was the best way for the apparel maker to save money moving forward."

Reintegration of activities that were outsourced before costs companies and results in significant organizational difficulties.

After years of outsourcing corporate processes and operational functions, many factors have now led to a rethink and the reincorporation of previously outsourced processes. One of the biggest dilemmas involved in an outsourcing initiative is how to mitigate the risk of failure. Why has outsourcing traditionally failed? In general, both clients (those who purchase outsourced services) and providers (those who perform the service) face threats and drawbacks (a) parting without having achieved their objectives, (b) encountering difficulties that result in contract renegotiation (or even remediation), (c) prematurely ending their arrangement, or (d) changing their initial objectives.

Naturally, decisions concerning organizational boundaries occupy significant room on the agenda of company executives in charge of strategy, IT, logistics, or management operations (Mol and Kotabe, 2011). Some companies also combine internal provision with outsourcing to external suppliers (Parmigiani, 2007) and take advantage of comparing between different modes of organization.

However, although outsourcing may bring several benefits to organizations, empirical evidence shows that there are some cases of reintegration. Despite there being well-known cases of outsourcing interruption ${ }^{2}$, academic literature focusing on reintegration is scant, probably because companies hardly ever report unsuccessful stories (Barthélemy, 2003). Nevertheless, 
what is reintegration? Three main features dominate. In our context reintegration in short refers to, first, a reversal of a former strategic decision. Second, it assumes the breaking of a contract with a provider. Finally, it involves the rehabilitation of the activity within the client company. Therefore, reintegration represents a shift in organizational company strategy that affects the sourcing structure. Moreover, the analysis of the underlying reasons of reintegration can help to understand better how organizational boundaries evolve (Cacciatori and Jacobides, 2005).

This paper analyzes some factors that might influence the reintegration decision. In order to understand the reasons why companies interrupt outsourcing, we use a single case study concerning the reincorporation of industrial maintenance activities in a metallurgy company in which outsourcing was discontinued after more than a decade of external provision and outsourcing. Then, we develop some propositions and offer an integrative framework for factors explaining the reintegration decision.

Based on our case study, for which 19 interviews were carried out, our empirical findings show that contractual hazards may explain the reintegration, which fits relatively well with some conclusions in the few previous works on reintegration (Barthélemy, 2003; Cacciatori and Jacobides, 2005; Whitten and Leidner, 2006; Frery and Law-Kheng, 2007). Our paper's contribution lies in the identification of further complementary determinants of reintegration: bandwagon behavior, and institutional pressure. Specifically, our paper refines Transaction Cost Economics (TCE) by exploring institutional theories and bandwagon behavior literature in an attempt to understand the dynamics of organizational boundaries. We find that the influence of external actors and the institutionalization of managerial practices also shape the behavior of decision makers in a complimentary fashion with contractual factors. These external influences 
may persuade companies either to outsource or reintegrate. Providing an integrative framework has led us to propose an innovative explanation of the main reasons why firms reintegrate.

Our work is organized as follows. The first section discusses the main theoretical reasons that might lead to reintegration from contractual and strategic management perspectives. We develop arguments based on TCE, incomplete contract and core competence theories. We also assume such a body of knowledge as being based on some theoretical arguments and information collected through a deep field study. Subsequently, we present our methodological stances and the results observed in our case study. Our sources involve face-to-face interviews and documentary analysis. Following this, we posit that although the existing theoretical predictions applicable to our case are interesting, they are not enough to explain the dynamics of reintegration entirely. Consequently, based on the matching between our empirical findings and theoretical discussion, we show that some other factors affect the decision to reincorporate activities formerly transferred to external actors. This integrative framework enables us to sketch a more comprehensive representation of reintegration determinants. The last section concludes and summarizes our main propositions.

\section{WHY DO FIRMS REINTEGRATE? MAIN THEORETICAL REASONS}

We define the reintegration phenomena as the decision to re-incorporate a given activity within a company that had formerly been transferred to an external supplier. The connections between outsourcing and reintegration are clear when considering the organizational boundaries choices. Indeed, we can understand outsourcing and reintegration as sides of the same coin, because the transfer of an activity by a firm implies its absorption by another outside entity. In the same vein, reintegration is associated with vertical or lateral disintegration (Lavington, 1927) and reintegration normally involves the breaking of outsourcing contracts and the reacquisition of 
resources, both human and material (Contractor, Kumar, Kundu and Pedersen, 2011). Thus, reintegration also requires the adaptation of organizational company structures to accommodate the undertaken functions or activities, which may pose problems to companies that depend on the supplier (or provider) for knowledge (Fine, 1998). This suggests that the costs of rebuilding formerly transferred capabilities may sometimes be significant. Indeed, re-enlarging the portfolio costs companies.

From the theoretical point of view, a considerable portion of the explanations for boundary choices, including reintegration phenomena, can be analyzed using TCE. Contractual maladaptation may lead to outsourcing failure, and thus undue outsourcing decisions are likely to be associated with future reintegration (Barthélemy, 2003a; Frery and Law-Kheng, 2007). Reintegration can also result from strategic behavior. Indeed, some organizations may attempt to reconfigure the institutional environment in which they are embedded according to their capabilities and strategic intents (Argyres, 1996; Jacobides and Winter, 2005) and external and environmental determinants may explain reintegration (Cacciatori and Jacobides, 2005). We further discuss the existing theories that shed some light on reintegration.

\section{TCE and the Intrinsic Factors leading to Outsourcing Failure}

TCE is one of the main frameworks used to focus on subjects related to organizational boundaries (Klein, Crawford, and Alchian, 1978; Anderson and Schmittlein, 1984; Williamson, 1991), outsourcing, and reintegration (Cacciatori and Jacobides, 2005).

Cost reduction is one of the major drivers of outsourcing decisions (Barthélemy, 2003; Greer, Youngblood, and Grey, 1999; Quélin and Duhamel, 2003; Mclvor, 2005). In situations involving specific assets, opportunism on the part of a supplier may arise. The safeguards to avoid ex-post hold-up are likely to increase contracting costs so that when assets are specific to 
transactions, firms tend to prefer internal forms of governance (Mayer and Salomon, 2006). Furthermore, the outsourcing of an activity related to organizational core competences and to high levels of asset specificity (Javidan, 1998; Prahalad and Hamel, 1990, Williamson, 1991) can undermine organizational efficiency, among other factors, because in this case it is more difficult to find suppliers to perform the activity (Cabral and Azevedo, 2008). The complexity of some contracts may lead to significant growth in the cost of their management and the core activities.

The incomplete nature of the contract also matters in outsourcing contracts. In fact, this is related to the agent's inability to verify the relevant variables (e.g., key performance indexes (KPI) and level of quality) and to build a clear and enforceable contract (Contractor et al, 2011; Saussier, 2000). Of course, organizations are in a position to develop managerial capabilities to design contracts that are more specialized and this would allow companies to outsource transactions with higher levels of asset specificity (Argyres and Mayer, 2007). In this case, firms need to maintain their technical capabilities (Parmigiani and Mitchell, 2005). Otherwise, they will not have the appropriate skills and devices for monitoring and controlling the supplier and will bear extra costs (Rothaermel, Hitt and Jobe, 2006).

Nevertheless, the building of trust-based relationships may attenuate the contractual hazards and some deficiencies in terms of managing the outsourcing relationship, even in the presence of specific assets (Dyer, 1997). The development of mutual trust between contracting parties may attenuate the hazards of self-interested behavior, thus sustaining successful partnerships and avoiding reintegration due to outsourcing failure (Lee et al., 2003). Incentivebased contracts, both implicitly and explicitly, also help to align the objectives of buyers and suppliers and foster successful outsourcing arrangements (Barthélemy, 2003). Conversely, the 
absence of such incentives in outsourcing contracts reduces the likelihood of the success of externalization and increases the probability of reintegration in the future.

\section{External and Environmental Determinants}

The literature is much less dense on the reasons to reintegrate. Two main changes can be mentioned: changes in the institutional environment and changes in the competitive landscape.

Among the main institutional changes, we can check: labor unions, professional monopolies (Cacciatori and Jacobides, 2005), and discretionary government intervention (Cabral, Lazzarini, and Azevedo, 2013). Some external pressure towards more labor regulation (O'Rourke, 2003) or avoiding job losses from outsourcing (Hira and Hira, 2005) may stimulate organizations to reintegrate functions that had formerly been transferred.

Reintegration also arises as a direct consequence of technological changes and shifts in the competitive environment (Muris, Scheffman, and Spiller, 1992; Ciarli, Leoncini, Montressor, and Valente, 2008)

\section{Strategic Intents}

Firms can also anticipate some trends and then shape their environment or be very reactive to some institutional changes. Companies are not always passive in the face of institutional change. In fact, organizations shape the institutional environment according to their strategic intents (Jacobides and Winter, 2005). Reintegration can also be seen as a conscious feature of a race pursued by organizations in an attempt to obtain competitive advantage.

In a complementary fashion, decisions of the scope of the organization rest on the available menu of internal resources and capabilities (Barney, 1991; Holcomb and Hitt, 2007; Quélin and Duhamel, 2003). Organizations can decide to internalize assets and organizational routines to better control the overall value chain (Fine, 1998). Therefore, reintegration may 
facilitate certain strategic intents: control of pricing (Worthen, Tuna, and Scheck, 2009), and gains in efficiency (Muris et al., 1992; Oliveira and Tolmasquim, 2004).

Such strategizing behavior of firms in reintegration decisions is consistent with the current institution-based view (Gil, 2010; Holt, 2001), in which managers make strategic choices within the institutional setting in which they are embedded. Moreover, informal ties may shape the rules of the game according to firms' strategic intents (Peng, Sun, Pinkham, and Chen, 2009). Actually, the reintegration phenomena may involve micro- and macro- levels of organizational analysis at the same time, thus requiring a more integrative framework.

\section{LESSONS FROM THE FIELD STUDY: MAINTENANCE IN METALLURGY}

\section{INDUSTRY}

In this section, we present and discuss the most relevant information collected during our field study. The empirical evidence helps us to understand the reasons why reintegration may occur. We use an explanatory case study (Yin, 1994) involving Organization X, a Brazilian company that interrupted the outsourcing of industrial maintenance by reintegrating the activity. After presenting our method, we discuss the case study. For the sake of clarity, we divide the presentation of our case study into three distinct parts: a) the reasons that resulted in outsourcing, b) the reintegration because of an outsourcing failure, and c) the influence of external determinants in the reintegration decision.

\section{Data Collection and Method}

In an attempt to tackle under-explored areas (Eisenhardt, 1989), we use a combination of documentary analysis and interviews. Primary data cover internal reports, contracts, meeting notes, labor union communications, and internal records concerning performance metrics (KPI). 
In-company data were collected between July 2006 and January 2007, and then in July 2012, i.e., after the decision of reintegrating.

In total, we performed 19 interviews. We ran semi-structured in-depth interviews with eight individuals from IT, contracting, maintenance, and production areas. We interviewed one of the company's managers twice (in 2007 and in 2012). The questionnaire ${ }^{3}$ contained open questions about facts, opinions, and expectations related to the investigated problem. In addition, we performed seven interviews with contractor executives and three other interviews with managers outside Organization $\mathrm{X}$ who had experienced some degree of reintegration in the past. These extra interviews were necessary to increase our understanding of the dynamics of the industrial maintenance sector in the geographic area of our study. Finally, all sources of data were triangulated to increase the credibility of our findings.

Two research assistants conducted the vast majority of the in-company interviews and both were briefed about the problem of reintegration and the context of the organization. The interviews were recorded and later transcribed. We codified and analyzed the texts in a standard tool for qualitative content and text analysis. The very fact that one of the authors has worked in the observed organization obliged us to double-check the interpretation of the meanings in order to minimize any potential bias. One author, who never worked before in Organization X, performed the analysis separately. Then, both interpretations were cross-referenced so that patterns of similarity and difference involving the two visions emerged, enriching the analysis. In order to mitigate reimaging and new biases, we refined our interpretations with the other coauthor of this paper, who was not engaged in the data collection. To guide our content analysis, we initially specified constructs according to the existing theories (e.g. contractual frictions, asset specificity, core competences). 
However, other aspects not previously foreseen in the theories such as institutional pressure and bandwagon behavior emerged in our analysis as potential explanations of the phenomena. On the one hand, the appearance of these new factors enriched our analysis; on the other, it forced us to work within a distinct path to tackle these new constructs.

\section{Case Study: Reintegrating Industrial Maintenance in a Metallurgy Company}

\section{Prelude: The decision to outsource industrial maintenance in Organization $\mathrm{X}$}

Organization $\mathrm{X}$ operates in the metallurgy sector and plays a leading role in its market. It has about 1,280 employees and annual revenue of US\$ 2.6 billion as of the end of 2011 . The quality of the Organization $\mathrm{X}$ products is widely recognized in the international market and exports represent $36.7 \%$ of total sales. The company has several above average performance indicators, and at the time of maintenance reintegration, it was on the list of one of the best 100 places to work in Latin America. The company also has a positive impact on the community environment: it received at the time of reintegration the Premium Partnerships Proof not Promises - Return on Environment from GE BETZ.

The production process begins with the receiving of the raw material-a special metal-and encompasses the concentrating, smelting and refining phases. All these activities are vertically integrated. Between 1982 (incorporation) and 1994 the maintenance activities were mainly carried out internally. In 1994, company X outsourced industrial maintenance covering electrical, mechanical and instrumentation areas. Maintenance was then brought back in house between 2004 and 2005.

Although some argue that industrial maintenance has a strategic role (Pinjala, Pintelon, and Vereecke, 2006), this function is commonly seen as a non-core function and a cost to be avoided, which might provide a good reason to outsource (Murthy, Atrens and Eccleston, 2002). 
Organization $\mathrm{X}$ adopted two outsourcing contract types in industrial maintenance services: person-hour assignment and turnkey contracts. ${ }^{4}$ Furthermore, Organization X kept on some maintenance employees to supervise contractors. Contracts were short-term lasting up to two years. Contractors included a leading European company in maintenance services and two major Brazilian players consolidated at the forefront of the local market.

Empirical evidence from several sources suggests that Organization $\mathrm{X}$ outsourced maintenance in response to external and internal pressures to reduce costs and increase competitiveness. On the external side, the decision to outsource is linked to the context in which such a practice was disseminated. In fact, at the end of the 1980s and the beginning of the 1990s, Brazil and other Latin American countries were suffering the effects of economic stagnation and hyperinflation (Baer, 2001). In response to the crisis, these countries implemented certain measures such as budgetary discipline, accountability measures and trade liberalization (Hay, 2001). Local companies that had not been exposed to fierce competition were suddenly impacted by a turbulent business environment, which forced them to implement best practice management principles in an attempt to promote efficiency gains (Carpinetti and Martins, 2001). In this sense, outsourcing was seen as a way to satisfy some organizational needs, namely cost cutting and focusing on core competences (Mclvor, 2005). According to one interviewee: “...cost reduction was our main focus when we outsourced" (Contract Manager).

Organization $\mathrm{X}$ was not immune to the influence of the unstable institutional environment and responded by following in the steps of other companies seen as benchmarks, as put by two employees:

"We went more or less on the same boat. Everybody was outsourcing." (Maintenance Chief \#3)

"The fashion was that (to outsource). The Japanese gave the example (...) most Japanese employees were outsourced." (Contract Manager) 
The decision to outsource was also to a certain extent influenced by external actors who played the role of advocates of new best practices that allegedly would contribute to reducing the workforce and cutting costs:

"At the time we decided to outsource, we had the influence of business schools, scholars, consultants, and managers who brought that (outsourcing) into the organization." (Contract Manager).

Despite the existence of such mimetic behavior, our empirical evidence confirms that Organization $\mathrm{X}$ executives performed a comparison of cost between internal provision and outsourcing before taking the decision to outsource. Indeed, at that time, contracting out seemed to be more cost-effective than internal provision. However, evidence also suggests that the outsourcing decision was taken without necessary examination of the peculiarities of this business environment:

"At the time we decided to outsource, we did not pay attention to several details. (...) Outsourcing was a fever. Everybody was looking for cost reduction." (Maintenance Supervisor \#1)

Outsourcing contracts presented several problems. Consequently, reintegration emerged as an alternative to address the weaknesses and flaws of outsourcing.

\section{Main Act: Reintegration because of an outsourcing failure in Organization $X$}

We discuss below some reasons able to explain the reintegration decision: gaps in cost reduction, changes in labor regulation standards, and contracting issues.

First, the expected savings were not achieved with outsourcing and this seems to be one of the main drivers of reintegration. The cost reduction expected with outsourcing did not occur. Although we were not in a position to audit the sources of the calculations done within Organization $\mathrm{X}$, we checked other sources to clarify and validate the numbers involved. Our 
triangulated data from internal reports and from the standard wages according to the labor union that represents maintenance workers in the region reveal that reintegration was expected to reduce maintenance costs by $38.6 \%$. At first glance, such a saving appears overestimated. Then, we compared the price increase in maintenance outsourcing contracts between 1999 and 2004 with the wage rises offered by contractors to their employees over the same period. To use the electrical maintenance services as an example, we can see that during this period the amount paid to contractors increased by $104 \%$, while the contractor's staff costs increased by only $47 \%$. The suppliers failed to pass on their increased income. In addition, costs increased because Organization X hired several contract supervisors to oversee contractor's employees as quality deterioration occurred.

"...in the first years was ok (outsourcing), because they (contractors) hired our former employees, but after some years as the experienced personnel quit or were allocated to other contracts, quality decreased....we suffered because the 'intelligence' was gone" (Maintenance Chief \#2)

The second driver of reintegration is related to changes in labor regulation. At the beginning of the outsourcing initiative, contractor employees earned lower salaries and had fewer fringe benefits compared to former employees of the Organization X performing the same activities. At the end of the 1990's and the beginning of the 2000's labor unions and prosecutors in charge of enforcing labor laws pressured companies to reduce these gaps. As a result, in several lawsuits courts ruled against companies who outsourced. Organization X was not an exception. In some lawsuits, judges determined that the company should provide the contractor's personnel with the same benefits granted to its own employees.

“...we had several litigations...some judges rule that outsourced employees must to have the same benefits our employees have..." (Maintenance Chief \#1) 
Besides the increasing pressure towards more strict regulation of outsourcing practices, our data collection reveals that there was a greater probability of outsourced employees being involved in accidents and suffering from occupational diseases. Triangulated data suggest that the lower qualifications the contractor's employees and their lack of commitment to internal work safety procedures explain the significant difference in terms of occupational hazards: three times higher for outsourced employees. Therefore, Organization X experienced legal disputes in this matter, and of course, this may link outsourcing and precarious work conditions, which may delegitimize outsourcing practices.

As Organization X could not avoid liability with regard to health and safety issues, the company increased the safety requirements for contractors and consequently contracting prices rose. Nevertheless, although the costs increased, the quality did not.

"...as the accidents were happening, we became more demanding and wrote in the contracts the safety requirements" (Maintenance Chief \#2)

Third, contracting issues are the third driver to reintegration. Interviews and other ancillary information obtained in our fieldwork confirm that Organization $\mathrm{X}$ ignored the influence of asset specificity in the decision to outsource, during ex-ante negotiations and during the execution phase of the contract. In fact, Organization X processes a special metal and the nearest similar plant is located more than $4,000 \mathrm{~km}$ away (in Chile). There is no similar company in the surrounding area and the equipment and technologies used are unique to Brazil. This imposes barriers to finding specialized suppliers to deal with such assets, especially for the maintenance activities. We found that some of the ex-employees of Organization X, laid-off due to outsourcing, were then hired by contractors and this could have mitigated the adaptation problems. However, these professionals either were allocated to other customers or simply left 
their jobs with contractors due to the low salaries. Thus, inexperienced personnel prevailed, as pointed out by interviewees:

"It takes some time to dominate the peculiarities of the business. Contractor employees may have experience in industrial maintenance, but they did not know our business and this takes time (...). During the period we experienced outsourcing it used to take about one year until the people (outsourcing contractor's employees) could walk on their own legs." (Maintenance Supervisor $\# 1)$

As the contracts lasted two years on average, the existing uncertainties regarding the continuation of the relationship seem to have forced contractors to earn as much as they could while they could. Income earned by contractors from customers was not transferred to contractor employees. In addition, this hold up compromised the quality of the work force assigned to Organization $\mathrm{X}$. Low qualification skills and high turnover rates were significant during the outsourcing experience of Organization X. They contributed to lowering the quality of services and led to reductions in productivity. One employee said:

"When he (outsourced employee) is about to get the knowledge, he quits or he is laid-off and another inexperienced professional shows up. This is even worse here (at Organization X) where we have equipment and machines with many peculiarities." (Maintenance Supervisor \#2)

The case unveils the very fact that the relationship between outsourcer and contractors was built in an uncertain atmosphere. Actually, the presence of uncertainty regarding contract renewal and the short time to cover the investment in specific human assets gave rise to underinvestment on the contractor's side in skilled labor. Our evidence shows that suppliers did not invest in the relationship due to the short contract term (up to two years) and did not exhibit the expected and necessary commitment. The difficulties associated with the allocation and retention of human resources are explicitly expressed here:

"Contractors hire people without experience using any criteria. There are no available qualified personnel to work in electrical, mechanical and instrumentation maintenance (...) they (the contractors) were simply allocating their personnel within our company, and thus leaving the responsibility with us.” (Maintenance Chief \#2) 
Agency problems (Jensen and Meckling, 1976) and increased transaction costs in the relationship (Williamson, 1991) are well illustrated in the quote below:

"Why should I make an effort today, if I do not know if I will be here tomorrow?" (Contract Manager of Organization X talking about how outsourced contractor staff and personnel allegedly think)

All these problems seemed to stimulate the reintegration of maintenance activities. We had access to the report prepared by middle managers for the newly appointed top executives of Organization $\mathrm{X}$ about the benefits of reintegration. We verified that in order to convince the top management about the feasibility of a reversal decision, they just had to prove that the decision would be cost-effective. Table 1 summarizes the internal report of Organization X comparing outsourcing and reintegration.

Insert Table 1 about here

\section{Epilogue: The influence of external actors on the decision to reintegrate}

According to the official vision expressed in meeting minutes and internal newsletters, a feasibility analysis was conducted and it unveiled potential advantages with reintegration in terms of cost, quality, work safety, and employees' mindset. Although the decisions to outsource and reintegrate were not taken by the same executives, a cost-benefit analysis was carried out on both occasions. However, unlike the first decision, empirical evidence reveals that Organization $\mathrm{X}$ progressively recognized industrial maintenance as a critical function, which represents a change in the shrewd perception of what belongs and what does not belong to the select group of core and critical activities. An employee illustrates this argument:

"We realized that we ought to reintegrate functions that are really attached to our production process." (Maintenance Chief \#1) 
This demonstrates that the problems that occurred during the outsourcing experience contributed to Organization X's rethink regarding the strategic role played by maintenance activities. Nevertheless, during our fieldwork we could perceive that Organization X benchmarked the example of companies located nearby in the decision to reintegrate industrial maintenance activities-as occurred in the decision to outsource. Although the nearest similar company is located thousands of miles away from Organization X, within a 30 kilometer radius some plants of the major Brazilian companies of the petrochemical and metallurgical sectors were located. These organizations exert influence on companies in close proximity, as stated by two interviewees:

"In Organization Y (benchmarking in the Brazilian metallurgy sector), they reintegrated almost everything, including maintenance services. Thus, we realized that it would be reasonable to reintegrate the maintenance functions.” (Maintenance Chief \#2)

"...they (Organization Y) used to have the same problems we had and they reintegrated maintenance" (Contract Manager)

Our evidence suggests that similar maintenance reintegration decisions taken by external actors helped Organization $\mathrm{X}$ to validate its own decision:

"...we needed to have some support for our decision (reintegration)...the fact that other firms had reintegrated helped the top management decision making process" (Maintenance Chief \#1)

The mimetic behavior once again observed during the reversal choice might signal precaution. In this sense, the rush to outsource was among the main elements responsible for the observed outsourcing failure in Organization X. This begs the question: Will such a problem occur again with reintegration? We can anticipate that the same unsuccessful dynamics may be repeated. In fact, the reintegration process in Organization $\mathrm{X}$ does not seem to be definitive. It is 
possible to identify some skepticism regarding the pertinence of reintegration as stated by two different employees:

"There is no rule about what is better. In our case, now the topic is to reintegrate. In the near future, I don’t know." (Maintenance Chief \#2)

"In my vision this is not a taken for granted, precise and mathematical issue. It depends on the moment." (Contract Manager)

The analysis of this case shows the importance of strategic choice or intents for outsourcing as well as reintegration. In fact, such decisions are very often about the perimeter of the portfolio of the company and require a fine understanding of the contribution of each activity to the creation of value and/or competitive advantage. This distinction is not neutral, as companies may feel that they work on an activity that is neither specific nor critical. However, it can play an important role in the building up of advantage over competitors. In addition, this case also highlights the role of the institutional environment. Finally, a longitudinal study of this case emphasizes the influence of managerial fads as best managerial practices, feeding mimetism.

\section{DISCUSSION: BUILDING AN INTEGRATIVE MODEL}

Empirical evidence indicates the relevance of contractual approaches as possible explanation of reintegration. However, during the process of data analysis some new facts have emerged and illuminated the reintegration phenomena, namely bandwagon behavior and institutional pressure.

We argue that some existing complementarities between the contractual approaches, bandwagon aspects, and institutional pressure can shed some light on real organizational problems, such as reintegration. We believe that one theoretical framework in isolation is not enough to explain the phenomena entirely. To analyze the reintegration problem, we discuss the potential contributions of each theory and then we move to an integrative approach. 
In this section, we offer eleven testable propositions and build a general framework for factors explaining the reintegration decision.

\section{Reintegration and Contracting Issues: Building a Collaborative Environment}

In the case of Organization $\mathrm{X}$, reintegration features an unsuccessful outsourcing process and it is very likely that reintegration occurred because outsourcing involved activities that should not be outsourced (Barthélemy, 2003). There are some reasons related to contracting aspects that may explain outsourcing failure and the consequential reintegration. Companies must be cautious with third party capabilities (Quinn, 1999). If executives do not have an accurate assessment regarding the aptitudes of candidate suppliers, outsourcing might be risky (Quélin and Duhamel, 2003).

This situation is particularly critical in certain industries where capable people are very few (Earl, 1996; Lonsdale, 2001). Alleviating the hazards of contractual friction in the presence of asset specificity, companies who want to promote outsourcing must signal to external providers that the specific investments made will be recouped (Aubert, Rivard and Patry, 2004).

Nevertheless, if a company chooses outsourcing it is necessary that managers know how to manage contracts and relationships with contractors (Earl, 1996). In this sense, the inability to specify contractual needs impedes companies from exploiting the benefits of outsourcing (Robinson, 2001). More specifically, managers must detail in outsourcing contracts: i) the scope of services to be delivered, ii) service levels and instruments to measure performance, iii) rewards, iv) termination provisions and the consequences of termination (Willcocks, Fitzgerald, and Feeny, 1995; Quélin and Duhamel, 2003). Otherwise, outsourcing is likely to fail and reintegration occurs. Thus, considering both the empirical evidence and theoretical arguments herein discussed, we can derive the following proposition: 
Proposition 1a: The lower the quality of the evaluation of the expertise of the contractor, the greater the likelihood of outsourcing problems, which lead to failure and reintegration

Proposition 1b: The greater the inability of the organization in specifying, monitoring and enforcing contracts, the greater the likelihood of outsourcing failure and reintegration

Several outsourcing contracts, including the contract analyzed before, use the so-called "body-shop" based relationship. Because this mechanism does not stimulate extra effort on the part of the contractor and incentives are low, this contractual mode does not align organizational objectives with contractual hazards correctly, which are essential factors in outsourcing performance (Leiblein, Reuer, and Dalsace, 2002). In this type of agreement, companies would be acquiring solely a work force, not services. Considering the absence of performance and productivity clauses, the possibilities of joint learning-for both buyer and supplier sides-are likely to be reduced. However, learning is an important factor in contracts of maintenance outsourcing (Tarakci, Tang and Teyarachakul, 2009). As third parties are not in a position to assume more responsibilities in the future, under these circumstances the outsourcing contracts do not stimulate third parties to exert extra effort (Saouma, 2008).

Because “...the level of fitness between the customer's requirements and the outsourcing outcome" (Lee, 2001: 326) is important, the service provider and client need to create an environment of mutual trust. Ability, benevolence, and integrity will influence the belief that each party involved in the relationship will behave accordingly. Trust also enables risk taking behavior from parties involved in a relationship (Schoorman, Mayer and Davis, 2007), which is a factor that may affect the degree of outsourcing success, even for maintenance outsourcing 
contracts. This reinforces the importance of trust at two levels: interorganizational trust and interpersonal trust at the individual level. However, in line with Zaheer, McEvily, and Perrone (1998: 156), "interpersonal trust by itself is insufficient for lowering negotiation costs" and interplay with interorganizational trust is necessary for the performance of outsourcing contracts (Willcocks and Kern, 1998).

In this vein, effective collaboration through knowledge sharing, self-enforced agreements for long term agreements seems to be a relevant way to improve performance in outsourcing contracts compared to traditional arm's length market relationships (Dyer, 1997; Dyer and Singh, 1998). Outsourcing performance can be boosted when relational aspects contribute to “...contractual refinements that further support greater cooperation” (Poppo and Zenger, 2002: 708). Subsequently we derive our second proposition:

Proposition 2: The lack of capacity of the organization in managing relationships and in creating trust based relationships leads to outsourcing failure and reintegration.

\section{"Me Too": Outsourcing and Reintegration as a Bandwagon Behavior}

Increasing competition in the last three decades has promoted some managerial techniques to a panacea status (Gill and Whittle, 1992). Among them, we find outsourcing, total quality control, and business process reengineering (Abrahamson, 1996; Guller et al. 2002; Lee and Chan, 2003). The adoption of some of these managerial tools was done in a bandwagon context (Malvey, Hyde, Topping, and Woodrell, 2000), and some innovations became similar to standards in industries (Abrahamson and Rosenkopf, 1997). Companies may accept managerial innovation. However, they should not rely exclusively on internal assessments of the efficiency returns of innovation. In this sense, bandwagon behavior may result when the threat of losing 
competitive advantage encourages organizations to adopt innovation (Abrahamson and Rosenkopf, 1993).

Bandwagon behavior correlates with decision makers' mindlessness, i.e. the willingness of individuals operating in a state of limited awareness that leads to rule-based conducts giving them the wrong perception of their environment (Fiol and O'Connor, 2003). Successful companies are likely to shape the behavior of other companies to an extent that the reputation of first movers influences the diffusion of managerial practices (Abrahamson and Fombrun, 1994). Non-adopters may have a shrewd perception that their performance is below average because of the non-implementation of the innovation (Lee and Chan, 2003). As pointed out by Nickerson and Zenger (2002: 548), “...fickle behavior need not be functional; structural choices may reflect processes of imitation in which the latest fads or fashions are adopted with only limited examination."

In general, companies (such as Organization X, our case study in this paper) may present inabilities in terms of making discriminating decisions when they face external pressures (Fiol and $\mathrm{O}^{\prime}$ Connor, 2003). We do not claim here that any management tool to be implemented should be treated as a management fad. Assuming that the decision to change the organizational boundaries is strategic and critical to a company's success, we might expect that a structural choice influenced by bandwagon effects without careful analysis can be correlated to an unsuccessful outcome ${ }^{5}$. Thus, in our context, we expect that the decision to reintegrate will be affected by bandwagon behavior in the following sense:

Proposition 3a: The greater the propensity of the organization to accept bandwagon behavior, the greater the likelihood of outsourcing failure and the greater the probability of reintegrating 
Proposition 3b: The greater the propensity of the organization to accept bandwagon behavior, the greater the likelihood of reintegrating

\section{Interactions between contractual issues and bandwagon effects}

Organizations tend to fit themselves into the environment and to seek legitimacy, recognition, and stability companies may institutionalize managerial practices, norms, and values (Haveman, 1993; Hall and Taylor, 1996; Scott, 2008).

In some cases, the organization culture or routines are strong enough to create barriers against mimetic pressure (Kondra and Hurst, 2009). In other cases, organizational resistance to bandwagon behavior (Oliver, 1991) is not sufficient to prevent companies from taking decisions that do not consider context-relevant aspects. Hence, the achievement of conformity through imitation may hamper detailed evaluations of critical contractual aspects, such as effective costbenefit analysis and required contractual safeguards.

Proposition 4a: When organizational culture is not strong enough to resist bandwagon pressure, the greater the likelihood of bandwagon pressure obstructing critical assessments of important contractual aspects and the greater the probability of outsourcing failure.

Proposition 4b: When organizational culture is not strong enough to resist bandwagon pressure, the greater the likelihood of bandwagon pressure obstructing critical assessments of important contractual aspects and the greater the probability of reintegrating. 
Benchmarking may act to compensate for the lack of available information. For some transactions, the assessment of the degree of asset specificity is straightforward. This is particularly true when a unique technology is involved or when the assets in question can be easily redeployed to alternative uses (Williamson, 1991). In these extreme cases, organizations can estimate the amount of necessary safeguards and then choose the organizational mode to economize transaction costs.

However, in practice managers sometimes have difficulty assessing the accurate level of asset specificity. The measurement of the degree of specificity can be costly or imprecise, which might constrain the choice of the appropriate governance structure. Managers may not be confident about what the real level of asset specificity is and consequently what the most appropriate organizational alignment should be.

Figure 1 (below) shows the area in which managers may hesitate in choosing one or another governance structure because they are not sure about the level of asset specificity and the related uncertainty. In this zone (denoted by $\delta$ ) managers may use the example of other successful companies to choose the governance mode.

Insert Figure 1 about here

In this manner, we argue that companies may practice bandwagon behavior when the level of asset specificity of the transaction under scrutiny is not clear. Imitation forced by mimetic devices can be an attribute that may also explain reintegration (or outsourcing) decisions. Thus:

Proposition 5a: Imitation explains outsourcing failure and future reintegration when the degree of asset specificity is not obvious. 
Proposition 5b: Imitation explains reintegration decisions when the degree of asset specificity is not obvious.

\section{Reintegration and Institutional Pressure}

Our empirical evidence illustrates that institutional pressure played some role in both the dissemination of outsourcing initiatives and in the subsequent reintegration. In fact, outsourcing is useful to address some of the challenges imposed by the modularization trends when complex production systems are involved (Baldwin and Clark, 2000). Outsourcing may also promote cost savings, especially when contractors have "...access to economies of scale that the outsourcer does not" (Quélin and Duhamel, 2003:648).

However, in some cases outsourcing enables cost-savings by bypassing regulatory controls and offering lower wages and benefits to outsourced employees (Johnstone, Mayhew, and Quinlan, 2000). In the last few years, normative institutions have permanently questioned the pertinence of outsourcing, mainly when job losses and/or precarious work conditions are associated with outsourcing (Kshetri, 2007). As in our empirical evidence, we can also verify some pressure exerted by external institutional forces against outsourcing in the United States (Biegelsen, 2012; Smith and Brand, 2009).

Customers may also exert pressure towards reintegration. In this vein, after offshoring call center operations to India, Dell reintegrated the activity in the US in response to customer complaints, which were tainting the company's image (Ren and Zhou, 2008). In Latin America, outsourcing of public services is associated to quality deterioration, and public opinion against privatization initiatives may explain the reintegration in public services (Cabral et al., 2013). 
Proposition 6: External pressures from the institutional environment stimulate reintegration when outsourcing is associated to deterioration in service quality and precarious working conditions.

\section{Interactions between changes in the institutional environment and contracting issues}

Our empirical evidence shows that pressure to improve occupational health and safety standards contributed to the increasing cost of outsourcing initiatives. Additionally, given that most cases in Brazilian labor courts are ruled in favor of the workers (Alston and Mueller, 2005), outsourcing seems to be less attractive in terms of cost savings compared to early 1990 's. The increase in the cost of outsourcing is also observable in other countries (King, 2008; Young and Maciniati, 2012).

From the contracting point of view, recent studies have demonstrated that outsourcing presents several hidden costs for coordinating and controlling contractor's activities in order to assure that established targets are met (Dibbern, Winkler, and Heinzl, 2008; Contractor et al., 2011) and when customer requirements are not fulfilled, reintegration is likely to occur as illustrated by the JP Morgan Case (King, 2005). Therefore, the combination of new pressure from the institutional environment and contracting flaws gives rise to our last proposition.

Proposition 7: Changes in the institutional environment accelerate reintegration when contractual hazards are present.

Table 2 shows the relationship between our findings and the theoretical propositions.

Insert Table 2 about here 


\section{An Integrative Framework for Reintegration}

Figure 2 summarizes a framework to explain reintegration based on the eleven propositions we developed above. In brief, the framework shows that reintegration can occur in response to outsourcing failure because of organizational strategic intents, bandwagon effects, and/or due to changes in the external environment.

Consistent with existing theories (Jacobides and Winter, 2005; Cacciatori and Jacobides, 2005) our framework assumes that deliberated strategic behavior may influence internal decisions on reintegration. The framework suggests that inherent contracting attributes and internal capabilities (such as contract management skills, ability to build trust based relationships, and aptitude for performing careful cost-benefit analysis of a managerial innovation) influence the likelihood of an unsuccessful outsourcing experience, thus favoring reintegration (see Propositions 1a, 1b, and 2). The framework shows that the organization's susceptibility to bandwagon pressure influences decisions of organizational boundaries (Propositions 3a and 3b).

Our framework assumes that institutional environment pressure may encourage reintegration decisions (see Proposition 6). Furthermore, we propose that contracting attributes and bandwagon factors may also interact in a joint fashion, thus explaining discrete choices on the organizational frontiers (see Propositions 4a, 4b, 5a, and 5b). Lastly, contracting issues and institutional pressure may also interact thus leading to reintegration (see Proposition 7).

Insert Figure 2 about here

CONCLUDING REMARKS: LIMITATIONS AND PERSPECTIVES 
The present paper contributes to management theory and to managing practices by discussing some possible reasons why organizations interrupt outsourcing and reintegrate. The case study used here supports some theoretical views and considers that reintegration might occur thanks to contractual hazards and because of outsourcing failure, i.e. reintegration may be the response to an unsuccessful outsourcing process. According to contractual approaches (Williamson 1991; Klein et al., 1978) and with the previous work on reintegration (see Barthélemy 2003; Cacciatori and Jacobides 2005; Whitten and Leidner 2006; Frery and Law-Kheng, 2007) we constructed propositions related to reintegration phenomena and set up an integrative framework.

Nonetheless, other factors emerged from the data we collected. Our case study suggests that bandwagon behavior could precipitate the adoption of outsourcing without proper thought being given to the matter. Under these circumstances, outsourcing is likely to fail and reintegration is a possible outcome.

In addition, propensity to adopt bandwagon behavior, organizational routines, and managerial fads may foster reintegration even if outsourcing did not result in complete failure. Although mimetic behavior is not new in management theory, to the best of our knowledge, no other works combine these aspects with contractual theories to discuss the dynamics of reintegration. Furthermore, the dialogue and cross-fertilization among different approaches (Nielsen, 2001) may be useful to understand complex subjects such as reintegration.

We do recognize that reintegration may be an organizational answer to a firm's boundary dynamics and to changes in the business environment. However, we decided to explore the avenue of reintegration because of an unsuccessful outsourcing implementation. In fact, we believe that scrutiny of unsuccessful stories and the examination of "what went wrong" 
potentially bring new learning opportunities and implications for theory and managers. Then we develop an integrative framework.

The present study has of course some limitations. The most evident is related to the methodological limits of case studies in terms of generalization. Second, although we made an effort to triangulate data and minimize biases, it is possible that our interpretations distort the reality of the investigated organization. Third, subjects relating to managerial fads and bandwagon effects emerged during the interpretation of our data. We did not have the opportunity to go back to Organization $\mathrm{X}$ to address those topics with all the interviewees again. Fourth, most part of the interviews were conducted by other experienced researchers rather than the authors. While such a procedure may avoid author biases, we are aware that missing points not captured by interviewers may exist. However, several informal interviews helped us to mitigate such inconveniences.

In spite of these limitations, there is room for important future investigations. One evident research path is to test our propositions in a multivariate context with several organizations that experienced reintegration of several functions or activities other than industrial maintenance. Quantitative analysis may explore additional causal relationships among contractual factors and the symbolic dimensions of reintegration. Although we did not find any support in our empirical research concerning the effects of new executives in the decision to reintegrate formerly outsourced activities, it is known that senior executive turnover affects strategy decision making and the firm's performance (Virany, Tushman, and Romanelli, 1992). Reintegration remains an under-explored topic, but there are several implications for different areas of management theory such as strategy, operations, and human resource management, among others. A more complete understanding of reintegration is crucial. 


\section{REFERENCES}

Abrahamson, E. 1996. Management Fashion. Academy of Management Review, 21: 254-285.

Abrahamson, E., and Fombrun, C. 1994. Macroculture: Determinants and consequences. Academy of Management Review, 19(4): 728-755.

Abrahamson, E., and Rosenkopf, L. 1993. Institutional and competitive bandwagons. Academy of Management Review, 18(3): 487-517.

Abrahamson, E., and Rosenkopf. L. 1997. Social network effects on the extent of innovation diffusion: A computer simulation. Organization Science, 8(3): 289-309.

Anderson, E., and Schmittlein, D.C. 1984. Integration of the Sales Force: An Empirical Examination. Rand Journal of Economics, 15(3): 385-395.

Argyres N. 1996. Evidence on the role of capabilities in vertical integration decisions. Strategic Management Journal, 17(2): 129-150.

Argyres, N., and Mayer, K. 2007. Contract design as a firm capability: An integration of learning and transaction cost perspectives. Academy of Management Review, 32(4): 1060-1077.

Aubert, B., Rivard, S. and Patry, M. 2004. A Transaction Cost Model of IT Outsourcing. Information and Management, 41(7): 921-932.

Baer, W. 2001. Brazilian Economy: Growth and Development. New York: Praeger, 5th edition.

Barthélemy, J. 2003. The seven deadly sins of outsourcing, Academy of Management Executive, 17(2): 87-98.

Biegelsen, A. 2012. Fedex fails to deliver for drivers, The Center for Public Integrity, April $2^{\text {nd }}$, Available at http://www.publicintegrity.org/2012/04/02/8565/fedex-fails-deliver-drivers, Retrieved in April, $3^{\text {rd }} 2012$.

Cabral, S. and Azevedo, P. 2008. The modes of provision of prison services in a comparative perspective. BAR: Brazilian Administration Review, 5(1): 53-69.

Cabral, S. Lazzarini, S. and Azevedo, P. 2013. Private entrepreneurs in public services: A longitudinal examination of outsourcing and statization of prisons, Strategic Entrepreneurship Journal, forthcoming.

Cacciatori, E. and Jacobides, M. 2005.The dynamic limits of specialization: Vertical integration reconsidered. Organization Studies, 26(12): 1851-1883.

Carpinetti, L. C. R. and Martins, R.A. 2001. Continuous improvement strategies and production competitive criteria: Some findings in Brazilian industries. Total Quality Management, 12(3): 281-291.

Ciarli, T. Leoncini, R., Montresor, R., Valente, M. 2008. Technological change and the vertical organization of industries. Journal of Evolutionary Economics, 18(3-4): 367-387.

Contractor, F.J., Kumar, V., Kundu, S., Pedersen, T. 2011. Global outsourcing and offshoring: An integrated approach to theory and corporate strategy. Cambridge University Press, p.3-47

Dibbern, J., Winkler, J., and Heinzl, A. 2008. Explaining variations in client extra costs between software projects offshored to India. MIS Quarterly, 32(2), 333-366.

Dyer, J. 1997. Effective interfirm collaboration: How firms minimize transaction costs and maximize transaction value. Strategic Management Journal, 18(7): 535-556.

Dyer, J. H., and Singh, H. 1998. The relational view: cooperative strategy and sources of interorganizational competitive advantage. Academy of Management Review, 23:660-679.

Earl, M.J. 1996. The risks of outsourcing IT, Sloan Management Review, Spring: 26-32.

Eisenhardt, K. 1989. Building Theories from Case Study Research, Academy of Management Review, 14(4): 532-550. 
Fine, C.H. 1998. Clock speed: Using Business Genetics to Evolve Faster Than Your

Competitors. London: Little, Brown and Co.

Fiol, C., O'Connor, M. and Edward J. 2003. Waking up! Mindfulness in the face of bandwagons, Academy of Management Review, 28(1): 54-70.

Frery F., Law-Kheng. 2007. La réinternalisation, chaînon manquant des théories de la firme, Revue française de gestion, 33: 163-179.

Gil, R. 2010. An Empirical Investigation of the Paramount Antitrust Case, Applied Economics, 42(2): 171-183.

Gill, J. and Whittle, S. 1992. Management by panacea: Accounting for transience. Journal of Management Studies, 30(2): 281-295.

Greer, C., Youngblood, S., and Gray, D. 1999. Human resource management outsourcing: The make or buy decision. Academy of Management Executive, 13(3): 85-96.

Hall, P. A. and Taylor, R. 1996. Political science and the three new institutionalisms. Political Studies, XLIV: 936-957.

Haveman, H. 1993. Follow the leader: Mimetic isomorphism and entry into new markets. Administrative Science Quarterly, 38(4): 593-627.

Hay, D. 2001. The post 1990 Brazilian trade liberalization and the performance of large manufacturing firms: Productivity, market share and profits. Economic Journal, 473:620 641.

Hira, R., Hira, A., 2005. Outsourcing America: What's behind our national crisis and how can we reclaim American jobs. AMACOM, New York, NY

Holcomb, T.R and Hitt, M.A. 2007. Toward a model of strategic outsourcing, Journal of Operations Management, 25: 464-481

Holt, J. 2001. In deregulation we trust: The synergy of politics and industry in Reagan-Era Hollywood. Film Quarterly, 55(2): 22-29.

Jacobides, M. and Winter, S. 2005. The Co-evolution of Capability and Transaction Costs: Explaining the Institutional Structure of Production, Strategic Management Journal, 26(5): 395-413.

Javidan, M. 1998. Core Competence: What does it mean in practice? Long Range Planning, 31(1), 60-71.

Jensen, M., Meckling, W. 1976. Theory of the firm: Managerial behavior, agency costs and ownership structure. Journal of Financial Economics, 3: 305-360.

Johnstone, R., Mayhew, C. and Quinlan, M. 2000. Outsourcing Risk - The Regulation of Occupational Health and Safety Where Subcontractors are Employed, Comparative Labor Law \& Policy Journal, 22, 351-393.

King, W.R. 2005. Outsourcing becomes more complex. Information Systems Management, 22(2): 89-90.

King, R. 2008. The new economics of outsourcing, Business Week, April, 07 ${ }^{\text {th }}$, Available at http://www.businessweek.com/stories/2008-04-07/the-new-economics-of-outsourcing, Retrieved in August, 31 2012.

Klein, B., Crawford, R., and Alchian, A. 1978. Vertical integration, appropriable rents, and the competitive contracting, The Journal of Law and Economics, 21(2): 297-326.

Kondra, A.Z. and Hurst, D.C. 2009. Institutional processes of organizational culture, Culture and Organization, 15(1): 39-58.

Kshetri, N. 2007. Institutional Factors Affecting Offshore Business Process and Information Technology Outsourcing. Journal of International Management, 13(1): 38. 
Lavington, F. 1927. Technical influences on vertical integration. Economica, 19: 27-36.

Lee, J.N. 2001. The impact of knowledge sharing, organizational capability and partnership quality on IS outsourcing success. Information and Management, 38: 323-335.

Lee, J.Y. and Chan, K.C. 2003. Assessing the operations innovation bandwagon effect: A market perspective on the returns, Journal of Managerial Issues, 15(1): 97-105.

Lee, J.N., Huynh, M.Q., Kwok, R. and Pi, S.P. 2003. IT Outsourcing Evolution: past, present and future.46(5), Communications of the ACM.

Leiblein, M.J. Reuer, J.J.. and Dalsace, F. 2002. Do make or buy decisions matter? The influence of organizational governance on technological performance, Strategic Management Journal, 23(9): 817-833.

Malvey, D., Hyde, J., Topping, S. and Woodrell, F. 2000. Getting off the bandwagon: An academic health center takes a different strategic path, Journal of Health Care Management. 45: 381-393.

Mayer, K., and Salomon, R. 2006. Capabilities, contractual hazards, and governance: Integrating resource-based and transaction cost perspectives. Academy of Management Journal, 49(5): 942-959.

Mclvor, R. 2005. The outsourcing process: Strategies for evaluations and management. New York: Cambridge University Press.

Mol, M.J., Kotabe, M. 2011. Overcoming Inertia: Drivers of the Outsourcing Process. Long Range Planning, 44(3): 160-178.

Muris, T., Scheffman, D. and Spiller, P. 1992. Strategy and Transaction Costs in the Carbonated Soft Drink Industry, Journal of Economics and Management Strategy, 1(1): 83-129.

Murthy, D.N.P., Atrens, A. and Eccleston, J.A. 2002. Strategic maintenance management. Journal of Quality in Maintenance Engineering, 8(4): 287-305.

Nickerson, J.A. and Zenger, T.R. 2002. Being Efficiently Fickle: a dynamic theory of organizational choice, Organization Science, 13(5): 547-567.

Nielsen, K. 2001. Institutionalist approaches in the social sciences: Typology, dialogue, and future challenges. Journal of Economic Issues, 35(2): 505-516.

Oliveira, R.G. and Tolmasquim, M.T. 2004. Regulatory performance analysis case study: Britain's electricity industry. Energy Policy, 32(11): 1261-1276.

Oliver, C. 1991. Strategic responses to institutional processes. Academy of Management Review, 16(1): 145-179.

O'Rourke, D. 2003. Outsourcing regulation: Non-governmental systems of labor standards and monitoring. Policy Studies Journal, 31: 1-29.

Parmigiani, A. 2007. Why do firms both make and buy? An investigation of concurrent sourcing. Strategic Management Journal, 28: 285-311.

Parmigiani, A., and Mitchell, W. 2005. How buyers shape supplier performance: Can governance skills substitute for technical expertise in managing outsourcing relationships? Academy of Management Proceedings, C1-C6.

Pinjala, S. R., Pintelon, L. and Vereecke, A. 2006. An empirical investigation on the relationship between business and maintenance strategies, International Journal of Production Economics, 104 (1): 214-229.

Poppo, L. and Zenger, T. 2002. Do formal contracts and relational governance function as substitute or complements? Strategic Management Journal, 23(8): 707-725.

Prahalad C.K. and Hamel G. 1990. The core competence of the corporation, Harvard Business Review, May-June: 79-90. 
Quélin, B. and Duhamel, F. 2003. Strategic outsourcing and corporate strategy, European Management Journal, 21(5): 647-661.

Quinn, J. B. 1999. Strategic Outsourcing: Leveraging Knowledge Capabilities, Sloan Management Review, 40(4):9-21.

Ren, Z. J. \& Zhou, Y.-P. 2008. Call center outsourcing: Coordinating staffing level and service quality, Management Science, 54(2): 369.

Robinson, B.B. 2001. Bureaucratic inefficiency: Failure to capture the efficiencies of outsourcing. Public Choice, 107(3-4): 253-270.

Rothaermel, F., Hitt, M., and Jobe, L. 2006. Balancing vertical integration and strategic outsourcing: effects on product portfolio, product success, and firm performance, Strategic Management Journal, 27(11): 1033.

Saouma, R. 2008. Optimal second-stage outsourcing. Management Science, 54(6): 1147-1159.

Saussier, S. 2000. Transaction Costs and Contractual Completeness, Journal of Economic Behavior and Organization, 42(2): 189-206.

Schoorman, F.D., Mayer, R.C. and Davis, J.H. 2007. An integrative model of organizational trust: Past, present and future, Academy of Management Review, 32(2): 344-354.

Scott, W.R. 2008. Institutions and Organizations: Ideas and interests. Thousand Oaks: Sage.

Tarakci H., Tang. K. and Teyarachakul, S. 2009. Learning effects on maintenance outsourcing. European Journal of Operational Research, 192 (1): 138-150.

Virany, B., Tushman, M., and Romanelli, E. 1992. Executive succession and organization outcomes in turbulent environments: An organizational learning approach. Organization Science, 3(1): 72-90.

Von Branconi, C., Loch, C. 2004. Contracting for major projects: Eight business levers to top management, International Journal of Project Management, 22:119-130.

Whitten, D. and Leidner, D. 2006. Bringing IT back: An analysis of the decision to backsource or switch vendors, Decision Sciences, 37(4): 605-621.

Willcocks, L. Fitzgerald, G., and Feeny, D. 1995. Outsourcing IT: The strategic implications. Long Ranging Planning, 28(5): 59-70.

Willcocks, L., and Kern, T. 1998. IT Outsourcing as Strategic Partnership: The Case of the UK Inland Revenue, European Journal of Information Systems 7(1): 29-45.

Williamson, O. 1985. The economic institutions of capitalism. New York: Free Press.

Williamson, O. 1991. Comparative Economic Organization: The Analysis of Discrete Structural Alternatives, Administrative Science Quarterly, 36(2): 269-296.

Worthen, B., Tuna, C. and Scheck, J. 2009. Companies more prone to go vertical. The Wall Street Journal, November 30th: A16.

Yin, R.K. 1994. Case Study Research: Design and Methods. Thousand Oaks: Sage.

Young, S., and Macinati, M. 2012. Health Outsourcing/Backsourcing. Public Management Review, 14(6):771-794

Zaheer, A. McEvily, B. \& Perrone, V. 1998. Does trust matter? Exploring the effects of interorganizational and interpersonal trust on performance, Organization Science, 9(2): 141159. 
TABLE 1

\section{Comparative Table Outsourcing vs. Insourcing Elaborated by Organization $\mathrm{X}$}

\begin{tabular}{|c|c|}
\hline Outsourced Personnel & Reintegrated Personnel \\
\hline Low qualified personnel. & $\begin{array}{l}\text { Assurance of manpower's qualification by using the } \\
\text { recruiting procedures of Organization X. }\end{array}$ \\
\hline Low levels of motivation and commitment. & There are more possibilities to motivate employees. \\
\hline $\begin{array}{l}\text { Contractual terms (every } 2 \text { years) generate } \\
\text { discontinuities in the process. }\end{array}$ & Probability of discontinuities in the process is lower. \\
\hline Total costs include labor costs and contractor's profit. & $\begin{array}{l}\text { Cost savings due to elimination of the contractor's } \\
\text { profit. }\end{array}$ \\
\hline Require the assignment of contract supervisors. & $\begin{array}{l}\text { Contract supervisors are not needed. Personnel can be } \\
\text { reallocated to maintenance activities. }\end{array}$ \\
\hline Increased odds of suffering labor accidents. & Labor accident risks decrease. \\
\hline Overestimation of the work force needs. & Fewer personnel needed. \\
\hline $\begin{array}{l}\text { More chances of having judicial disputes in labor } \\
\text { courts. }\end{array}$ & Judicial dispute odds are lower. \\
\hline
\end{tabular}

\section{FIGURE 1}

Uncertainty zone of asset specificity degree (Adapted from Williamson, 1991)

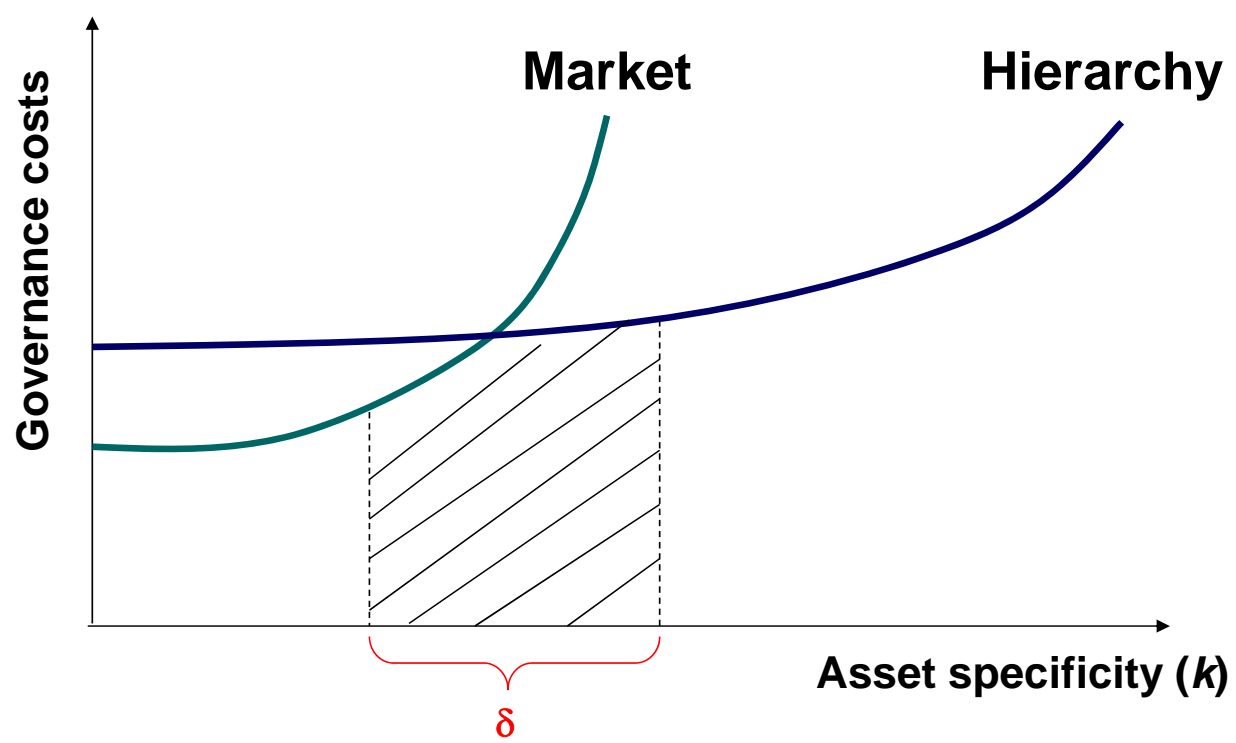

"Where am I here?" 
FIGURE 2

Factors affecting the decision to reintegrate: An integrative framework

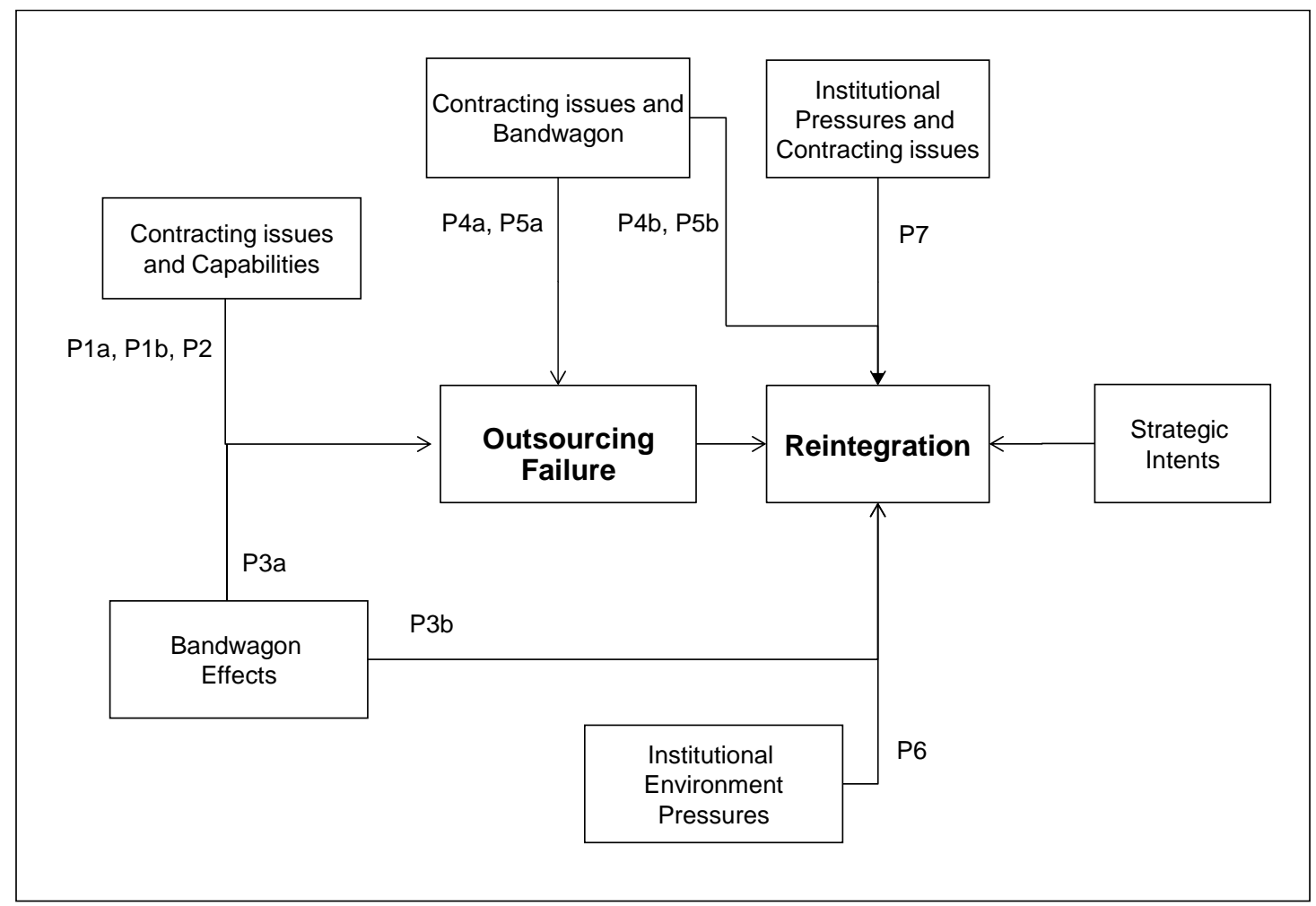

${ }^{1}$ CIO, February 18, 2010

- http://www.cio.com/article/549463/Company_Saves_Millions_By_Ending_IT_Outsourcing_Deal

${ }^{2}$ Such as the reintegration of maintenance functions taken by rail companies in the United Kingdom (Mclvor, 2005) and JP Morgan's decision to perform IT functions that it had previously outsourced (King, 2005),

${ }^{3}$ Available upon request.

${ }^{4}$ Person-hour (also known as time and material contract) comprises a fixed fee that covers the hours of labor of the professionals involved in operations. In this arrangement contractors have weak incentives to improve performance standards. The latter involves the contracting of a company for a specific task or bundle of activities. In turnkey contracts, the external provider takes the responsibility for fixing and leaving the equipment ready for operation. This contract type leads to allocation of more responsibilities to the contractor, and the underlying incentives to increase performance indicators are stronger (Von Branconi and Loch, 2004). Organization X contracted on a turnkey basis for more complex events.

${ }^{5}$ This analysis must also address the consistency and continuity of organizational routines. Are they able to support change or otherwise be the cause of conservative mechanisms even more rejection? We thank one of the reviewers to have indicated this interaction between routine and bandwagon effect. 
TABLE 2

Translation of Case Study Findings into Testable Propositions

\begin{tabular}{|c|c|c|c|c|}
\hline Driver & Case study Info & $\begin{array}{c}\text { Benchmarking / } \\
\text { Similarities }\end{array}$ & Findings & Testable Propositions \\
\hline $\begin{array}{l}\text { Contracting Issues } \\
\text { and Collaborative } \\
\text { Environment }\end{array}$ & $\begin{array}{l}\text { - Outsourcing of maintenance, } \\
\text { - "we did not pay attention to several details" } \\
\text { - Key performance indexes (KPI) and level of } \\
\text { quality, } \\
\text { - "Cost reduction" } \\
\text { - "Contractors hire people without experience" }\end{array}$ & $\begin{array}{l}\text { The UK rail network } \\
\text { operator (Mclvor, 2005), } \\
\text { Problems in IT Outsourcing } \\
\text { (Aubert et al 2004), } \\
\text { Joint learning (Tarakci, Tang } \\
\text { and Teyarachakul, 2009). }\end{array}$ & $\begin{array}{l}\text { Low level of expertise. } \\
\text { Inability to monitor and enforce } \\
\text { contract } \\
\text { Inability to manage relationships } \\
\text { and create trust }\end{array}$ & $\begin{array}{l}\text { Outsourcing failure and reintegration (P1a, } \\
\mathrm{P} 1 \mathrm{~b})\end{array}$ \\
\hline Bandwagon Behavior & $\begin{array}{l}\text { - Impact on the community environment } \\
\text { - "Everybody was outsourcing", } \\
\text { - "The Japanese gave the example" }\end{array}$ & $\begin{array}{l}\text { Nickerson and Zenger } \\
(2002) .\end{array}$ & $\begin{array}{l}\text { Propensity to follow a } \\
\text { bandwagon behavior }\end{array}$ & $\begin{array}{l}\text { Outsourcing failure and reintegration (P3a) } \\
\text { Likelihood to reintegrate (P3b) }\end{array}$ \\
\hline $\begin{array}{l}\text { Contracting Issues } \\
\text { and Bandwagon }\end{array}$ & $\begin{array}{l}\text { - "influence of business schools, scholars, } \\
\text { consultants, and managers" without careful } \\
\text { perusal; } \\
\text { - "we suffered because the 'intelligence' was } \\
\text { gone" }\end{array}$ & $\begin{array}{l}\text { Oliver (1991). } \\
\text { Williamson (2008). }\end{array}$ & $\begin{array}{l}\text { Weak organizational culture and } \\
\text { insufficient critical assessments } \\
\text { Non-obvious level of asset } \\
\text { specificity }\end{array}$ & $\begin{array}{l}\text { High probability to imitate, then leading to } \\
\text { fail and reintegration }(\mathrm{P} 4 \mathrm{a}, \mathrm{P} 4 \mathrm{~b}) \\
\text { High probability to imitate and to fail } \\
\text { (P5a, } \mathrm{P} 5 \mathrm{~b})\end{array}$ \\
\hline Institutional Pressure & $\begin{array}{l}\text { - Changes in labor regulation standards } \\
\text { - "we had several litigations... some judges } \\
\text { rule that outsourced employees must to have } \\
\text { the same benefits our employees have", } \\
\text { - Benchmark companies "reintegrated almost } \\
\text { everything" }\end{array}$ & $\begin{array}{l}\text { - Precarious working } \\
\text { conditions under } \\
\text { outsourcing (Kshetri, } \\
\text { 2007), } \\
\text { - Market power of customers } \\
\text { and/or suppliers (Muris et } \\
\text { al, 1992, Worthen et al, } \\
\text { 2009), } \\
\text { - Dell in India (Ren and } \\
\text { Zhou, 2008) }\end{array}$ & External pressures. & High probability to reintegrate (P6) \\
\hline $\begin{array}{l}\text { Institutional } \\
\text { environment and } \\
\text { contracting issues }\end{array}$ & $\begin{array}{l}\text { - Courts and contracting costs } \\
\text { - "we became more demanding and wrote in } \\
\text { the contracts the safety requirements" } \\
\text { - Customer demands and contracting costs }\end{array}$ & $\begin{array}{l}\text { - UK building industry } \\
\text { (Cacciatori and Jacobides, } \\
\text { 2005), } \\
\text { - Prisons in Brazil (Cabral et } \\
\text { al, 2013), } \\
\text { - United States vs. Fedex } \\
\text { (Biegelsen, 2012) }\end{array}$ & $\begin{array}{l}\text { Contractual hazards and changes } \\
\text { in institutional environment }\end{array}$ & Likelihood to reintegrate (P7) \\
\hline
\end{tabular}


